\title{
Counselling Experience Among Malaysian Adolescent Who Are Involved in Ilicit Sex Behaviors
}

\author{
Ruhani Mat Min, PhD \\ School of Social and Economic Development, Universiti Malaysia Terengganu, Malaysıa \\ Tengku Teh Mariah Tengku Jewa \\ Universiti Kuala Lumpur, Malaysıa
}

Doi:10.5901/mjss.2015.v6n2s1p316

\begin{abstract}
This qualitative study aims to describe the counselling experience among adolescent who are involved in illicit sex behaviour. Three adolescent girls, who are currently participate in rehabilitation programme at a center, were selected as research participants. Participants were selected based on (i) they are involved in illicit sex behaviour previously, and (ii) they are participating in counselling session. Data were gathered through semi-structured interviews and journal writing. The data involved three interviews and a series of journal writing, were gathered over a period of six weeks. The results show that emotional experience was the main issue presented by the participants of this study. The three themes related to emotional experience were identified as a sense of calm, able to control their emotion, and ready to face challenges. The implications of these findings are that counselling sessions provide opportunities for adolescents, who are involved in illicit behaviour to experience unconditional acceptance, to have positive feelings, be more open to new experience and to help them to recognize the potential within themselves.
\end{abstract}

Keywords: Adolescent illicit sex behavior, Counselling session, Emotional experience, Qualitative research

\section{Introduction}

Adolescence is a period of transition from childhood to adulthood and an important phase of developmental stage in an individual's life, which occurs between 11 and 21 years old. This developmental stage involves biological, psychological, social changes, as well as changes related to levels of maturity (Azizi, Jaafar, Shahrin \& Yusof, 2005). Prior to that, Hall (1904) suggests the phenomenon of "storm and stress" with adolescents, stands as a full-time chaos, full of adventure, physically, intellectually and, socially rebellious against adult authority.

Adolescence is considered to be a stage where many people have engaged in behavior problems (Hashim, Khairulhelmi, Mohamed Fahmi \& Syafeq, 2008) including risk behavior, sexual problems, physical changes, and dramatic behaviour. Zainal and Mohd Sharani (2004) explain that at this age, adolescents have a high curiosity. Therefore, any new experience happens around them will encourage the existence of curiosity within them. This opinion is supported by Romzi (2006), who stated that the main reason why teenages are involved in risky activities is to seek pleasure without thinking. The stronger the desire to seek pleasure, the lower the internal control within him or herselves. A review by Khadijah, Salina, Fauziah, Noremy, Mohd Suhaimi \& Noorhasliza (2012) stated that adolescents who become pregnant out of wedlock do not have an attachment with their parents, which then leads to unhealthy sexual activity. The study also showed that the living environment, peer influence, and exposure to adolescent sexual activity partly contributed to may become pregnant out of wedlock. However, a study by Zainuddin and Norazmah (2011) showed different results, the main factor involved in adolescent social problems is a desire to try something new; rather than the influence of family background. Zainuddin and Norazmah's (2011) findings are consistent with previous studies. Ezhar, Jusang, Mohd Rezal and Zamree (2007) conducted a study on the social problems of young people from low-income families in the city, and found that environmental factors in schools are significant predictors of social problems. This means that exposure to a negative school environment, such as a low commitment to school and teachers' low expectations, partly contribute to involvement in social problems among students. In other words, the environment has an important role in shaping the behavior of adolescents or young adults. The study also showed that media exposure is a risk factor in young working adults. This means exposure to risk factors of media contributes to increased involvement in social problems.

Kolberg (1968) discussed moral development and proposed three stages, namely; pre- conventional, conventional, 
and post-conventional. Adolescents and adults are at the conventional level. This stage has two priorities; the first of which is interpersonal. The focus of this stage is individual behavior that allows working with partners and the community. At this stage, individuals need the acceptance of others for their behaviour. The second priority is to maintain current levels of conventional social rules. During this stage, individuals begin to appreciate the social rules that exist. Good behavior means complying with laws and social rules.

Counselling experience provides an opportunity for changes in attitude and behaviour of a person through a working relationship between a counsellor and a client. Usually, individuals who seek counselling feel like they were not perfect and require assistance for a change to happen in terms of personal development, mental, emotional, and behavioral problems (Othman, 2005). Counselling experiences are able to positively impact on short-term and long-term changes, as well as have an impact on the development of a more positive self (Zuria, Noriah, and Amla, 2005; Zainuddin, Zuria and Salleh, 2008). The findings of this study also suggested that clients get their confidence back, get an insight about family relationships, gain support, and build more effective behavior. According Zuria et al. (2005), the effectiveness of the counselling sessions can be evaluated through the aspects of behavior, thoughts, and feelings of the client during the session in progress.

Azizi, Anuar, Rahim and Yusof (2001), conducted a study that aimed to examine the effectiveness of the implementation of the programme at the centre of protention for women and girls. Their results showed the effectiveness of the guidance and counselling program is at an average level. Despite that, the results indicated that the counsellor had won the trust of clients. Counsellors have been perceived helping the clients to solve problems and reduce feelings of tension. Also, the counsellor is seen as sincerely trying to help. A review by Rusnani, Loh \& Asmah (2008) suggests that the counselling services in helping students at Malaysian higher education institutions are at a medium level. In other words, these services have not been accepted by the public in spite of being introduced fifty years ago. Despite that, the study (Rusnani et al., 2008) showed that respondents who had gone through the counselling experience had a more positive attitude than those who had not been through the experience of counselling.

Rogers (1961) suggests that humans have an internal power and the potential to make themselves successful and useful to society. According to Rogers, an individual experiencing unconditional acceptance or 'unconditional positive regard' will be more open to understanding their experience. Also, potential and openness will grow well if they are in a condusive environment. Potential, openness, and development, will contribute to high self-concept. All these, potential, openness and development, can be achieved in stages (Othman, 2005).

The Person Centered Theory, put forward by Rogers (1961), also suggests that humans are naturally good, rational, responsible, and strive for self-actualization. However, people also tend to be frustrated and distressed when unable to strive for self-actualization as a result of failing to experience love and security. Disequibelirium occurs when there is a discrepancy between self-perception and actual self. This causes confusion and tension in individuals.

According to the Social Learning Theory (Bandura, 1977), human behavior is the result of interaction to environmental issues and pressures. Bandura (1977) also states that individuals will behave based on the experience of seeing others that are considered as models. In relation to this, rewards can avoid delinquent behavior and produce good behavior (Bandura, 1977). On the other hand, individuals are not in a vacuum when dealing with environmental demands. Individuals have the ability to choose their behaviours when they are participated in the environment (Ruhani, 2009). This means that individuals don't only receive pressures from the environment. Individual experiences are the result of interaction between the components of self, and the environment (Ruhani, 2009).

Adolescents like to search for fun without thinking (Romzi, 2006). Adolescents who become pregnant out of wedlock do not have an attachment to their parents (Khadijah et al., 2012). The main factor involved in adolescent social problems is a desire to try something new that has not been tried before (Zainuddin and Norazmah, 2011). Counselling services contribute to a more positive self-development (Zuria et al., 2005; Zainuddin et al., 2008; Rusnani et al., 2008). According to Rogers (1961), an individual who is experiencing unconditional acceptance will be more open to understanding what they have experienced. In short, there are many elements interacted during adolescence and counselling experience offers unconditional acceptance. Therefore, this study aims to understand how the adolescents who involved in illicit sex behaviours encounter their counselling experience.

\section{Methodology}

This study is a qualitative research. Qualitative methods allow the experience of participants to be interpreted and explained in the context of a specific environment (Denzin \& Lincon, 2000). Qualitative findings are generally disclosed or reflected in language or words used day-to-day and often incorporate the words of the participants themselves to describe a psychological event, experience, or phenomenon (Patton, 2002). 
Population of this study consisted of adolescents at rehabilitation centres. From the information obtained from the centre, there are a large number of inmates who involved in sex out of wedlock and some of them involved in illicit sex behaviours. Purposive sampling was employed in selection of research participant. The participants consisted of three teenagers who are participating in rehabilitation at the center and involved in illicit sex behaviours previously. These participants are currently attended counseling sessions.

This study aims to understand how the adolescents who involved in illicit sex behaviours encounter their counselling experience. The focus of this research is not to search for objective facts and truth about this experience, but the main interest lies in the subjective experience captured in the individual stories of adolescents. The qualitative approach is most appropriate choice because qualitative researchers study things in their natural settings, attempting to make sense of phenomena in terms of the meaning people bring to them (Denzin \& Lincon, 2000).

Data were gathered through a series of semi semi-structured interview and journal writing. A semi-structured interview required an interview protocol, which is a list of questions, was prepared prior to the individual interview sessions. According to Patton (2002), a semi-structured interview prompts researchers to ask questions in a systematic and structured way. However, the answers given by participants have no limits or special structure. This method aims to identify the views of study participants, related to the process of counselling, with the hope of obtaining in-depth information. Each participant was interviewed three times during a six-week period.

Journal writing refers to a note or record of thoughts, feelings, opinions, or actions. Journal writing were prepared by the participants on a weekly basis. Entries in the journal described their experiences during the six weeks study period, and approximately six journals for that period. The participants were suggested to write about themselves, especially about their daily feelings, thoughts, and actions. In addition, study participants were asked to write about the perceived changes within themselves after each counselling session.

Data analysis was conducted based on the guidelines proposed by McLeod (2001). Based on these guidelines, all three interviews were recorded and listened to, also the transcriptions of the interviews, and the diaries were read several times. Data sources, such as interviews and diaries were read concurrently, in order to get the entire experience of the participant. Significant statements related to the participants experiences are listed.

\section{Findings}

The background of the research participants, Diana, Sarah and Mimi are as follows:

\section{Diana}

Diana, 19 years old, felt rejected by her birth mother, as a child born out of wedlock. Diana was raised by her grandmother from infancy to age five. Following that, Diana was sent by her grandmother to an orphanage until to age of 14 years old. Diana forced to leave the orphanage, because she was involved in an uncontrol behaviours. After being expelled from the orphanage, she lived with her aunt. However, Diana's mother came to take her from her aunt. Diana's mother exposed her to work at a night pub. Diana was not comfortable with this work, and ran away to her aunt's house. Diana continued to stay with her aunt. At her Aunt's house, Diana was almost raped by a relative of her aunt. She recounted the incident to her aunt, but her story was questioned by her aunt. Diana ran away to her grandmother's house. At 16 years of age, Diana started to have sex out of wedlock, even though it started with some coercion. These sexual activities continued until she became pregnant. However, she underwent an abortion, after she learned that her partner had relationships with other women. After that, Diana engaged in sexual activities with numerous partners, until she had an affair with a drug dealer. Diana lived in the same house with the drug dealer, which was eventually raided by the police. She was then ordered to stay in a rehabilitation centre for two years.

\section{Sarah}

Sarah, 19 years old, is the first child of four siblings. Her mother is a housewife and her father is a labourer. Sarah involved in behaviour problems before stayed in a rehabilitation centre. She spent most of her night time with activities that related to behaviour problems. Advises from her parents was ignored. This lifestyle brought Sarah to practice sex out of wedlock from the age of 12. Eventhough Sarah was not ready to have sex with her boyfriend at the first time, but after some persuasion, she agreed. Following this incident, Sarah became addicted to sex, and had sex with many men. However, Sarah's boyfriend did not know about her sexual activities with other men. Sarah became pregnant with her boyfriend, but underwent an abortion, because she was still at 13 years old. Sarah's life style continued, and she did not 
listen to the advice of her parents. As a result of her life style, the family made a report to the authorities; and finally, Sarah was ordered into a rehabilitation centre for a period of two years.

\section{Mimi}

Mimi, 17 years old, is the second of five brothers and sisters. Mimi was often beaten by her father, which caused her to be very afraid of him. However, her father was not at home often, because he had two wives. Mimi left home freely when her father was not at home. This behavior began while she was at the age of 13 years old. According to Mimi, her relationship with her siblings led her to having sex out of wedlock. Furthermore, she was often beaten by her mother. According to Mimi, her mother beat her because she wanted to release pressure. Mimi was often out having fun with male friends. Mimi had sex out of wedlock with her boyfriend while she was at the age of 14 years old. Following that, she also had sex with another boyfriend. Her boyfriend promised to marry her, but he left. Mimi's next experience was being raped by a security guard. The incident was reported by her family to the authorities. As a result, Mimi was sent to a rehabilitation centre by court order for two years.

Emotion is the main factor in the stories Diana, Sarah and Mimi. Three themes related to emotion were identified as (1) a feeling of calm, (2) able to control emotions, and (3) ready to face challenges.

\subsection{Feeling Calm}

The three participants in this study did not go through the same number of counselling sessions. However, the effectiveness of the counselling sessions can be seen when the participants felt calm as a result of this experience.

According to Diana (not her real name), having someone that can listen and understand, can indirectly help in managing her emotion. This is experience was expressed by Diana,

"Here .... you can share with the counsellor and the principal only .... because they are the right people to talk to. When I talk, they will not tell to other people. They kept this story to themselves ... I feel comfortable ... and calm. She understands me .. it's peaceful ....."

Diana also stated that this feeling of calm had a positive impact on her, which helped her to think and learn better. Here is an excerpt from Diana,

"After counselling.... I felt calm .. I was thinking, I plan what I want to do for myself in the future. I can learn with a peaceful mind ...."

Another participants, Mimi (not her real name) also had quite similar experience, a feeling of calm helped her in learning experience. Here is an excerpt from Mimi,

" ... I felt peaceful after expressed everything... I underwent counselling sessions 4 time. When I let it all out, I felt comfortable. Then I want to learn.

Diana also expressed her feeling of calmness after sharing her problems with the counsellor in her journal.

"... When I see a counsellor, I feel calm. I can fully express my feeling... " (Diary 1: Diana).

A sense of calmness was the result of the encouragement and enthusiasm provided by the counsellor to her. Here is an excerpt from her journal,

" ... The counsellor gave much encouragement and helpful advice to me. In terms of feeling, I felt calm ... " (Diary 6: Diana).

Another participant, Mimi, feeling of calmness was happened after expressed her fear and concern on the issue of security, especially when she heard that her ex-boyfriend was still looking for her. Here is an excerpt from Mimi,

" ... all what I can say about Ms SSSS ... her advice and words of encouragement made me feel calm ... " ( Diary 3 : Mimi). 
The same feeling was mentioned by Sarah, and she felt relaxed after expressing the problems that disturbing her mind. Here is an excerpt from Sarah,

"... When I meet with the counsellor, I was glad to be able to express the issues that borthering my mind ... I feel calm, I want to study ... " ( Diary1: Sarah).

Sarah added that before meeting with the counsellor, her heart and mind were not at peace. However, being able to talk to the counsellor, she felt calm with herself:

" ... Before I met the counsellor, I felt very uneasy. However, after we met, I could express to my heart's content, and had a sense of relief. I felt very relaxed ... " (Diary 4: Sarah).

\subsection{Able to Control Emotions}

Counselling experience provides a new perspective on emotional reactions of the research participants. They mentioned their ability to control their feelings of anger, hostility and frustration in their stories.

According to Diana, she can feel her emotions and feelings change after several counselling sessions, she is able to control her behavior of a hot temper.

This is Diana's story,

“... result of counselling I can take care of people's feelings, can speak properly, can control my emotions. I manage to control my hot-tempered ..."

Diana also feels that her emotion is stable right now, she is able to control the situation. This is Diana's story,

"...I used to have a strong emotional reaction. Hot-tempered all the time while living with my aunt. At the same time I was quite, not willing to talk to anybody. But when my aunt alway mention my bad behaviour... I became very emotional. Then we have a big fight. When I am here, starts to think back, ... O God, I used to have bad behavior. Now, I have better emotion reaction. At the prayer room, I can talk politely to other people, and advice them to talk slowly. I think I can be a leader ... I was about to finish my rehab programme .. almost time to go back home ..."

Diana is confident with her changes. According to her, she is in control of her feelings compared to her beginning of stage at the rehabilition center. She could not accept the fact that she need to stay in the center. However, she has a different perspective now. She is no longer rebellious and being able to wait until the end of the rebilitation programme.

This is Diana story,

"...My confidence level is eight (scale of eight out of ten). I can get full when getting married later. Previously, I always involved in negative behaviours but things are different now. Previously, I always thought of run away from this rehabilition center. I always wanted to rebel. The counsellor at center once told me that men will sell me, live in destitute, hard life. Men can do anything thing toward us. So, we need to be patience, and stay here. We need to wait to finish. The important thing is our level of patience need to be strong..."

Mimi also encountered quite similar experience, which is she can control her emotions and feelings better after several counselling sessions with a counsellor. This is Mimi's story,

"...I think I am able to control my temper now. Previously, I cannot manage my emotional reactions, but after I have counselling sessions I can manage my emotional reactions a little bit ..."

".... That day, I told the counsellor that I had a fight with one member at the center. The counsellor told me that maybe I misunderstood on the issue. When I think back about the fight, I was emotional at that time. The counsellor suggests to apologize to that member. I did apologize to the person. After that we became friend. I feel calm after that. I learned to calm down. Even my temper temperament has changed. Previously, I always rampage when I have a fight with friends. Now, I think differently, I think rampage is not a good behaviour ... "

Mimi added her story that she is happy with her present situation, which is able to control her emotional reaction whenever challanged by unexpected situation. She is also able to control her emotion, particularly not transfer her anger to other people. This is Mimi's story, 
"...Now, I am not tranfered my tension to other member. Before, I always cried when encountered tension. Things are different now. I am not crying when I feel tension. I am not an emotional person now. I feel that I am now a cheerful person."

Sarah shared that her experience in counselling sessions developed her patience in herself. This is Sarah's story,

"...I used to have no patience and was always emotional. Things are different when at this center, engage in counselling, listen to their advice. After sometime, patience in me starts to develop. Currently, I am able to control my emotions..."

Sarah also said previously, she was easily transferred her anger to other people. However, her situation changed after participated in counselling session. Sarah stated that she is more in control of her emotional and feelings.

\subsection{Ready to Face Challenges}

The effectiveness of the counselling process can also be seen when the participants mentioned in their stories about their readiness to face challenges. Those challenges included challenges throughout the period of rehabilitation programme as well as challenges that need to face from the outside world later. Diana shared her experience being bullied by a lesbian at the center at the beginning of the rehabilitation programme. However, she felt not afraid of that person anymore. Diana admits that she grew stronger after getting support and strength from the counsellor. Here is an excerpt from Diana:

" ... I shared my problem with the counsellor. I am not afraid of them anymore. There are different kinds of issues happen here .... bully is one of them. They want to show who has the power .... I feel relaxed now. If I face with problem, I know where to go ... I feel ok now. Sometimes I feel depressed ... at the beginning stage of my present at this center ... I was pressured by lesbian. She wanted to do bad things with me ... so I wanted to run away from this center ... because I felt depressed ... but when I saw barbed wire ... I do not dare to continue that .... the staff caught me ... they sent me to the lockup. I share with the counsellor when I feel depressed ... "

Diana will be completed the rehabilitation programme soon and she stated her readiness to face with all the challenges and tribulations later, which is resulted from her counselling sessions. Here is an excerpt from the interview with Diana,

"... I do not know when, sooner or later ... financial problems, family problems ... all kinds of problems ... with friends or neighbours ... But I feel ready to face all those ... I always feel afraid but things are different now ... after going through counselling sessions, I am ready to face hurdles in life ..."

For Mimi, she would try her best to face challenges in life as she had encountered some time ago. Mimi's hope stated as follows,

"... Once I completed this rehabilitation programme, it is God willing, I will try to face all challenges, tribulations and temptations. God willing, I will avoid all the previous behavior ... I hope that after this I was not lured by the persuasion of men ... nowadays men are not sincere. Then I will not believe words of this kind of guys ... for me these guys are useless. I hope I can cope with all the challenges of this life ... "

For Sarah, the counsellor helped her to become more confidence to go through this life. Sarah admitted to having been confronted with accusations, but after expressed her depressed to the counsellor, she managed to wake up and ready to face challenges. Now, she is ready to face any problems and challenges and no longer feel depressed because she believed that there is a way out for every problem. Excerpts of the interview with Sarah is as follows,

$"$... For me, the counsellor is like one of life partner. When I faced a hard life, she is my friend ... she helps me whenever I needed her. For me she is everything. She could wake me up from being weak to become strong ... from collapse to remain stand tall. She understands my feelings. When I faced with accusations or anything ... I'll deal with all that. The counsellor always said do not run away from problems ... if we run from this problem, another problem will come. So do not run away from problems ... Now I feel strong ... strong to bear any risk. If there is a problem I will talk and not wash my hands. One more ... I have not turn back. I want to move forward ... "

According to Sarah, her courage and strength is the result of counselling experiences. Sarah also stated, counselling is an important event in her life. These experiences help her to become more courageous to face the outside 
world later. Expression of Sarah's feelings is as follows,

"... For me it should be continued in order to help myself move forward and be strong to face the outside world later. For me, these counselling experiences are another priority in my life because I would see the counsellor whenever I have any problem. I can cry at her. I think after completed this rehabilitation programme I would go to counselling session too ..."

Diana also stated that she is ready to meet challenges and expectations when dealing with the outside world later. Excerpts of Diana's journal is stated as follows,

"... This day I am starting to feel that there is a big change in my life. Now, I feel more relaxed. I am ready to face any challenge. What happened is a test on me. God want to test me. So patience is very important in life ... " ( Diary 4 : Diana )

Mimi was trying to fight the feeling of fear when confronted with her previous boyfriend. She gained the strength after met with the counsellor to share her feelings.

$"$ "... She suggested to ignore him if I bumped into ex-boyfriend ... pretend to not know him. The counsellor suggested to avoid thingking about him. I think I could face if I bumped into him. I want to be brave. Why is that I should afraid. Most important is I need to know how to take care of myself ... " ( Diary 3 : Mimi )

Sarah also had the courage to deal with the challenges and turbulations during her stay at the rehabilitation center after getting support from the counsellor.

"... I have been here more than 2 year, I have to face many challenges ... I have been accused of stealing .... I can face it with courage and I can deal with people who accused myself ... " ( Diary 1 : Sarah )

\section{Discussion}

The feeling of calm is an important aspect that can affect the whole life of an individual. This feeling can give a sense of happiness, comfort and joy to the individual. The findings are in line with previous findings that counselling experiences contribute to positive self-development (Zuria et al., 2005; Zainuddin et al., 2008; Rusnani et al., 2008). This research showed that the participants feel calm after they went through counselling experiences. This finding suggests that one way to reduce stress is to talk to someone. Able to express their feelings in the counselling sessions help the participants to relief their stress, anxiety, as well as feeling of depressed. They also confessed that they are no longer burdened with the problem. The results also showed that a sense of calm that resulted from counselling sessions can affect their concentration in their studies. Feeling calm experienced by study participants occurred gradually after engaging in number of counselling sessions. The participant experiences are related to the ideas forward by Rogers (1961) that humans have the potential to make themselves successful.

The participants in this study indicated that the counselor listened, supported and understood their stories. Having someone to listen, support and understand contribute to a sense of calm. Related to this, Rogers discusses the issue of unconditional acceptance by the counsellor that allow the client to accept him or herself (Thorne, 2003). According to Diana, Mimi and Sarah, the acceptance that showed by the counsellor helped them to accept their inappropriate behavior as a part of themselves. As a result of this, they are willing to change their attitudes that more suitable and comfortable with themselves. Able to behave in behaviour that comfortable to themselves provide a sense of calm. Individuals who have experienced unconditional acceptance will be more open to understand their own experience. Also, potential and openness will grow well if they are in a conducive environment. These three participants, Diana, Mimi and Sarah, began to recognize their potential and contributed to their good self-concept.

Ability to control emotions and feelings is an important aspect in promoting emotional well being of an individual. Findings in this study indicated that the ability and capacity of the participants to manage their emotions as well as feelings in their daily life. The stories shared by Diana, Mimi and Sarah indicated that they can manage their emotions and negative feelings after went through the counselling experiences with the counsellor. These participants shared how their patience developed as a result of the counselling experiences. They became more patience when confronted with depressed situations. Experience in the counselling sessions encourages them to become more tolerant and willing to accept feedback from others. Changes in emotion as experienced by the research participants can be understood from the idea described by Kolberg (1968), the stage of moral development in adolescents and young adults. The three 
participants in the study indicated that they need the acceptance of others. Because of the needs, the participants had involved in the immoral activities. The opportunity to engage in counselling sessions with the counsellor enables them to develop their understanding on the social rules. Ability to understand the social rules, allowing them to realize that their previous behaviors were not suitable and they promise to themselves not to repeat those behaviours.

Ready to face the challenges of any situation means that an individual has the courage and prepared to take on all obstacles that come into her or his life. The findings of this study showed that this situation exists within the research participants, Diana, Mimi and Sarah. They have the courage to face all the possibilities that will happen in their lives, either at the rehabilitation center or at the outside world later. The participant stories indicated that their courage started to flourish after experienced support from the counsellor. Despite that, the research participants expressed their courage from a different point of view. There are participants who expressed their courage to face the temptations and persuasion of male, and another participant mentioned her courage to face the friends at the rehabilitation center. Related to this, Tudor, Keemar, Tudor, Valentine, \& Worrall, (2004) stated that relationships with others help individuals understand themselves better. The uniqueness of the individual is also a result of his or her relationship with other people.

\section{Conclusion}

Experience went through counselling sessions enable the adolescent who was involved in illicit sex behaviour encountered feelings of calm, in control of emotion and ready to face all the challenges. An adolescent moral development focuses on interpersonal relationships and followed by a focus on the behaviors that enabled her to work with other people and member in the community. An opportunity to engage in the counselling sessions with the counsellor allows the adolescent who is involved in the illicit sex behaviour to evaluate her behavior thus make assessment that enable them to work together with other people. Relationship with the counsellor also allows them to experience unconditional acceptance, which is helping them to discover their potential and being open to the experience and their environment.

\section{References}

Azizi Yahaya, Anuar Rahman, Rahim Hamdan dan Yusof Boon (2001). Program pemulihan akhlak wanita: Sejauhmanakah keberkesanan pusat perlindungan wanita membantu proses pemulihan? (Female rehabilitation programme: To what extent effectiveness of women's shelter in helping the healing process?). Persidangan Kebangsaan Pendidikan Moral Dalam Globalisasi di Universiti Malaya pada 23 - 25 Mei 2001.

Azizi Yahaya, Jaafar Sidek Latif, Shahrin Hashin \& Yusof Boon (2005). Psikologi Sosial Alam Remaja (Social Psychology for Teenager). Pahang: PTS Publications dan Distributors Sdn. Bhd.

Bandura, A. (1977). Social Learning Theory. Eaglewood Cliffs. Prentice-Hall.

Denzin, N. K. and Y. S. Lincoln (2000). (Eds.) Handbook of Qualitative Research (2nd edition). Thousand Oaks, California: Sage Publications.

Ezhar Taman, Jusang Bolong, Mohd Rezal Hamzah dan Zamree Yaakob (2007). Masalah Sosial dan Kesedaran Sivik Generasi Muda Daripada Keluarga Berpendapatan Rendah Di Bandar (Social Issues and Civic Awareness among Younger Generation From Low-Income Families in an Urban Environment). Laporan Penyelidikan Diserahkan kepada Institut Penyelidikan Pembangunan Belia.

Hall, G. S. (1904). Adolescence: Its Psychology and Its Relations to Physiology, Anthropology, Sociology, Sex, Crime, Religion, and Education. 2 vols. New York, Appleton.

Hashim Bedu, Khairulhelmi Katip, Mohd Fahmi Mohd Sahid \& Syed Mohamed Syafeq Syed Mansor (2008). Keruntuhan akhlak dan gejala sosial dalam keluarga; isu dan cabaran (Moral decay and social problems in the family; issues and challenges). Seminar Kaunseling Keluarga, 30 Ogos 2008, Johor Bahru, Malaysia.

Khadijah Alavi, Salina Nen, Fauziah Ibrahim, Noremy Md. Akhir, Mohd Suhaimi Mohamad \& Noorhasliza Mohd Nordin (2012). Hamil Luar nikah dalam kalangan remaja (Out of wedlock pregnancy among teenagers). Jurnal e-Bangi, 7 (1), 131-140.

Kolberg, L. (1968). The child as a moral philosopher. PSYCHOLOGY TODAY, Sept, 2(4), 24-30.

McLeod, J. (2001). Qualitative Research Method in Counselling and Psychotherapy. London: Sage Publications.

Othman Mohamed (2005). Prinsip Psikoterapi dan Pengurusan Dalam Kaunseling (Principles of Psychotherapy and Management in Counselling). Serdang: Universiti Putra Malaysia.

Patton, M. Q. (2002). Qualitative Evaluation and Research Methods. (3nd ed.). Thousand Oaks, California: Sage Publications.

Rogers, C. (1961). On Becoming a Person: A Therapist's view of psychotherapy. London: Constable.

Romzi Ismail (2006). Penglibatan Remaja Dalam Perlumbaan Motosikal Haram: Peranan Keluarga dan Masyarakat Dalam Menangani Gejala ini (Youth Involvement in Illegal Motorcycle Racing: The Role of Family and Community in Addressing Symptoms). Universiti Kebangsaan Malaysia: Pusat Pengajian Psikologi dan Pembangunan Manusia.

Ruhani Mat Min (2009). Budaya Sekolah: Implikasi Terhadap Proses Pembelajaran Secara Mengalami (School Culture: Implications of 
Experiential Learning). Jurnal KEMANUSIAAN, 13, 63-78.

Rusnani Abdul Kadir, Loh Poh Fang \& Asmah Ismail (2008). Hubungan Pengalaman Melalui Kaunseling Dan Sikap Mendapat Bantuan Kaunseling (Relationship Between Counselling Experience and Attitude Getting Counseling Help). Jurnal PERKAMA, $14,97-106$.

Thorne, B. (2003). Carl Rogers ( $2^{\text {nd }}$ edition). London: Sage Publications

Tudor, L. E.; Keemar, K.; Tudor, K.; Valentine, J.; and M. Worrall (2004). The Person-Centred Approach. A Contemporary Introduction. Basingstoke: Palgrave Macmillan.

Zainal Madon dan Mohd. Sharani Ahmad (2004). Panduan Mengurus Remaja Moden (Guide to Managing Modern Youth). Bentong: PTS Professional Publishing Sdn. Bhd.

Zainuddin Abu, Zuria Mahmud \& Salleh Amat (2008). Pendekatan Kaunseling, Menangani Masalah Kebebasan Dalam Kalangan Pelajar Institusi Tinggi: Dua Kajian Kes (Counselling Approach, Addressing Freedom Among Students in Higher Institutions: Two Case Studies). Jurnal Pendidikan, 33, 107-128.

Zainuddin Sharif dan Norazmah Mohamad Roslan (2011). Faktor-faktor yang mempengaruhi remaja terlibat dalam masalah sosial di Sekolah Tunas Bakti, Sungai Lereh, Melaka (Factors influence youth involvement in social problems at Sekolah Tunas Bakti, Sungai Lereh, Melaka). Journal of Education Psychology \& Counseling, 1, 115-140.

Zuria Mahmud, Noriah Mohd. Ishak, Amla Salleh (2005). Masalah Tingkahlaku Pelajar Dan Strategi Kaunselor Sekolah Di Malaysia (Student Behavioral Problems And School Counsellors' Strategies in Malaysia), Prosiding Seminar Pendidikan Serantau UkmUnri Ke 2, 2, 451-464. 